\title{
KINERJA RSUD WANGAYA KOTA DENPASAR BERBASIS BALANCED SCORECARD
}

\author{
Ni Nyoman Tri Wahyuni ${ }^{1}$ \\ Luh Gede Sri Artini ${ }^{2}$ \\ ${ }^{1}$ Fakultas Ekonomi dan Bisnis Univesitas Udayana, Bali, Indonesia \\ email: twahyuni387@gmail.com \\ ${ }^{2}$ Fakultas Ekonomi dan Bisnis Univesitas Udayana, Bali, Indonesia
}

\begin{abstract}
ABSTRAK
Penelitian ini membahas tentang pengukuran kinerja RSUD Wangaya Kota Denpasar sebagai organisasi sektor publik berstatus BLUD dengan menggunakan metode Balanced Scorecard (BSC). Tujuan dari penelitian ini adalah untuk mengetahui dan mengenal kinerja RSUD Wangaya Kota Denpasar secara komprehensif dengan metode BSC selama kurun waktu tiga tahun yaitu tahun 2014 sampai tahun 2016, meliputi empat perspektif yaitu perspektif pelanggan, perspektif keuangan, perspektif proses bisnis internal dan perspektif pembelajaran dan pertumbuhan. Hasil penelitian kinerja RS secara menyeluruh memperoleh nilai $73 \%$, memperoleh kualifikasi dengan nilai Baik dengan tingkat keberhasilan tergolong Berhasil.
\end{abstract}

Kata Kunci : Balanced Scorecard, Indeks Komposit, Pengukuran Kinerja

\begin{abstract}
The research discusses the performance measurement of General Hospital of Wangaya Denpasar City as public sector organization with status of Regional Public Service Agency by using method of Balanced Scorecard (BSC). The purpose of the research was to investigate and analyze the performance of General Hospital of Wangaya City Denpasar comprehensively by Balanced Scorecard method for three years from 2014 to 2016, covering four perspectives: customer perspective, financial perspective, internal business process perspective, and perspective of learning and growth. The results of the study showed that the overall performance measurement of the hospital obtained a score of 73\%, with qualification of good rating with success rate classified as successful..
\end{abstract}

Keywords: Balanced Scorecard, Composite Index, Performance Measurement 


\section{PENDAHULUAN}

Seiring tekanan terhadap organisasi sektor publik, khususnya organisasi daerah dituntut untuk memperbaiki kinerjanya (Mahmudi, 2010), dimana Rumah sakit merupakan usaha pelayanan publik dengan ciri khas memberikan pelayanan medis dituntut hal yang sama untuk memperbaiki kinerjanya (Fatmanelly, 2011). Penilaian kinerja yang digunakan selama ini dengan metode lakip, yang menitik beratkan pada evaluasi kegiatan sedangkan data yang berasal dari medikal rekord belum dianalisa secara optimal, hal ini dapat dilihat dari penurunan jumlah pendapatan, jumlah pasien kunjungan rawat inap dan rawat darurat tidak mencapai target, dan tidak stabilnya kinerja indikator mutu pelayanan, hal ini tidak menjadi bahan kajian bagi pihak manajemen.

Kinerja sektor publik bersifat multidimensional sehingga tidak ada indikator tunggal yang dapat digunakan untuk menunjukkan kinerja secara komprehensif, Adanya kelemahan yang bisa disebabkan karena ketidakseimbangan penilaian kinerja, maka pihak manajemen dituntut untuk mencari alternatif lain. Pengukuran kinerja $B S C$ merupakan alternative pengukuran kinerja yang cocok untuk rumah sakit karena mempertimbangkan keseimbangan internal dan eksternal, ukuran aspek finansialnya dan aspek non finansial serta kinerja jangka pendek dan jangka panjang.

Rumusan masalah dalam penelitian ini, $B S C$ mengukur kinerja berdasarkan empat perspektif, yaitu perspektif Pelanggan, perspektif Keuangan, perspektif 
Proses Bisnis Internal, perspektif Pembelajaran dan pertumbuhan serta kinerja RSUD Wangaya secara keseluruhan (indeks komposit).

Tujuan penelitian ini adalah untuk mengetahui dan mengenal kinerja RSUD Wangaya Kota Denpasar dengan metode BSC yang meliputi : perspektif Pelanggan, perspektif Keuangan, perspektif Proses Bisnis Internal, perspektif Pembelajaran dan pertumbuhan serta kinerja RSUD Wangaya secara keseluruhan (indeks komposit).

Manfaat Penelitian ini secara teoritis diharapkan memberikan kontribusi dalam bentuk empiris tentang penerapan metode BSC dalam penilaian kinerja RSUD Wangaya Kota Denpasar dan manfaat praktis untuk meningkatkan akuntabilitas dan transparansi pelayanan kesehatan di RSUD Wangaya Kota Denpasar, dapat digunakan sebagai alat evaluasi kinerja sebagai acuan dalam meningkatkan kinerja RSUD Wangaya Kota Denpasar baik dari segi keuangan maupun non keuangan untuk selanjutnya dapat memperbaiki kinerja periode berikutnya dan memberikan gambaran informasi untuk ditindaklanjuti dalam menetapkan kebijakan strategi RS.

\section{LANDASAN TEORI}

Menurut Mardiasmo (2002), sektor publik merupakan suatu entitas yang aktivitasnya berhubungan dengan usaha untuk menghasilkan barang dan pelayanan publik dalam rangka memenuhi kebutuhan dan hak publik. Tujuan utama sektor publik adalah tidak untuk memperoleh keuntungan tetapi untuk 
menciptakan nilai bagi organisasi tersebut, organisasi sektor publik terfokus pada misi organisasi dan masyarakat dianggap sebagai klien (Barbara Bigliardi, 2011).

Menurut Suparto (2002), teori manajemen yang digunakan dalam penelitian ini, yang terkait dengan sektor publik ( rumah sakit) yaitu : Manajemen Pemasaran RS secara garis besar dianalisa bahwa terdapat pertukaran antara RS ( layanan kesehatan ) dengan pasien ( imbalan jasa ), manajemen keuangan RS diberi wewenang mengelola sendiri uang dari hasil pendapatannya dengan masih tetap mengikuti aturan-aturan yang ditetapkan oleh induknya, manajemen sumber daya manusia dapat dibagi menjadi tiga jenis yaitu Tenaga full timer, Tenaga part timer, Tenaga contract, manajemen operasi RS dengan adanya sarana dan fasilitas RS untuk menunjang proses pelayanan kesehatan RS dapat diklasifikasikan dalam lima tipe kelas yaitu Kelas A, Kelas BI, Kelas B II, Kelas C, Kelas D. Bangunan RS dan fasilitas, alat-alat kesehatan, sumber daya manusia, dana yang tersedia dengan melalui proses POAC manajemen yang baik.

Pada awalnya BSC dikembangkan Oleh Robert S. Kaplan dan David P. Norton sebagai alat pengukuran kinerja yang digunakan untuk perusahaan bisnis komersial (Kaplan dan Norton, 1996). BSC itu Diusulkan sebagai alat pengukuran kinerja multi dimensi (Kaplan dan Norton, 1992), namun fokusnya segera beralih ke manajemen kinerja (Kaplan dan Norton, 2001a, 2001b) Potensi manajemen kinerja BSC didasarkan pada asumsi bahwa hubungan kausal ada antara keempat dimensi. Menurut Kaplan dan Norton (1996a, hal 65). Hubungan sebab akibat ini menunjukkan arah untuk memperbaiki hasil pada indikator "leading" (tiga 
dimensi pertama) pada akhirnya akan mendorong peningkatan kinerja pada dimensi keempat, "lagging" pada perspektif keuangan (Deryl Northcott, 2011).

Perkembangannya BSC tidak hanya sekedar alat pengukuran kinerja, tetapi sebagai sistem manajemen strategik perusahaan yang digunakan untuk menerjemahkan misi, visi, tujuan, dan strategi ke dalam sasaran strategik dan inisiatif strategik yang komprehensif, kohern, dan terukur (Mahmudi, 2010). BSC adalah alat konseptual dari empat perspektif yang dapat dimodifikasi (Farshad Behrouzi,2014). Manajemen strategis adalah proses kunci untuk mencapai organisasi visi, strategi dan tujuan. Semua organisasi harus melakukan praktek manajemen strategis untuk memastikan bahwa mereka cocok dalam lingkungan (Abdel, 2014). BSC terdiri dari dua kata: kartu skor/scorecard, dan berimbang/balanced (Mahmudi,2010). Kartu skor yang dirancang harus mencakup sistem peringatan untuk keberhasilan atau kegagalan dari sasaran, dilakukan antara data aktual dan nilai target yang ditetapkan (Hsueh Fen Chen, 2012)

Perkembangan BSC telah mengalami beberapa generasi yaitu generasi pertama tahun 1990-1991 digunakan sebagai alat untuk melakukan pengukuran kinerja melalui pendekatan empat perspektif. Generasi kedua adalah untuk memperbaiki kekurangan dengan membuat hubungan sebab akibat antara berbagai ukuran kinerja tersebut. Generasi ketiga BSC merupakan perbaikan model dengan penekanan pada perbaikan fungsi dan lebih menekankan pada relevansi strategi (Mahmudi, 2010). BSC terbukti efektif untuk mendasari masalah yang ada dan mengidentifikasi peluang untuk perbaikan tepat waktu, menyajikan model 
terstruktur BSC di sistem kesehatan masyarakat Yunani sudah baik dengan hasil positif di tingkat manajemen puncak (Yiannis Koumpouros,2012).

Kaplan dan Norton (1996) membagi perspektif pelanggan menjadi dua kelompok pengukuran, kelompok pertama yaitu pangsa pasar, retensi pelanggan, akuisisi pelanggan, kepuasan pelanggan, profitabilitas pelanggan . Kelompok ukuran kedua merupakan faktor pendorong kinerja pembeda hasil pelanggan untuk mengukur proporsisi nilai pelanggan menyatakan atribut yang diberikan perusahaan kepada produk dan jasanya untuk menciptakan loyalitas dan kepuasan pelanggan dalam segmen pasar sasaran. Perspektif pelanggan dalam organisasi sektor publik merupakan komponen yang paling penting dari empat perspektif BSC terhadap kinerja organisasi (Seth A Oyugi, 2013), merupakan tumpuan (leverage) utama karena tujuan organisasi sektor publik secara makro adalah untuk menciptakan kesejahteraan masyarakat. Berdasarkan pedoman survey kepuasan masyarakat terhadap penyelenggaraan pelayanan publik dengan peraturan menteri pendayagunaan aparatur Negara dan reformasi birokrasi Republik Indonesia nomor 16 tahun 2014 tentang Survei Kepuasan Masyarakat yang berpedoman pada Indeks Kepuasan Masyarakat (IKM) KepMenPan No. KEP/25/M.PAN/2/2004.

Perspektif keuangan menurut Kaplan dan Norton (1996) membagi daur hidup bisnis menjadi tiga tahapan : Bertumbuh ( Growth), Bertahan (Sustain), Menuai (Harvest). Perspektif keuangan dalam organisasi sektor publik terkait dengan upaya untuk meningkatkan kinerja keuangan dengan cara meningkatkan pendapatan dan sekaligus mengurangi biaya,dimaksudkan untuk meningkatkan 
kemandirian fiskal yang dapat digunakan untuk meningkatkan pelayanan (Mahmudi, 2010). Terkait dengan strategi perspektif keuangan bertujuan untuk jangka panjang dari organisasi untuk memberikan hasil yang unggul berdasarkan modal yang diinvestasikan (Ayesha Farooq, 2011). Menurut kementerian keuangan Republik Indonesia Direktorat Jenderal Perbendaharaan, Peraturan direktur jenderal perbendaharaan nomor per 36 /PB/2012 tentang pedoman penilaian kinerja keuangan satuan kerja badan layanan umum direktur jenderal perbendaharaan.

Perspektif Proses Bisnis Internal menurut Kaplan dan Norton (1996) mengamati rantai nilai generik memberi suatu template yang dapat disesuaikan oleh setiap perusahaan dalam mempersiapkan perspektif setiap bisnis internal, model tersebut terdiri dari tiga proses bisnis utama yaitu proses inovasi, proses operasi, Layanan Purna Jual. Perspektif proses internal pada organisasi bisnis dengan organisasi sektor publik pada dasarnya adalah sama, yaitu untuk membangun keunggulan organisasi melalui perbaikan proses internal organisasi secara berkelanjutan. Beberapa sasaran strategik pada perspektif proses internal misalnya peningkatan proses layanan, perbaikan siklus layanan, peningkatan kapasitas infrastruktur, pemutakhiran teknologi (Mahmudi, 2010). Berdasarkan Peraturan Menteri Kesehatan Republik Indonesia, Nomor 1171/Menkes/Per/VI/2011, Berdasarkan Juknis Sirs, tahun 2011, variabel yang digunakan untuk menilai rumah sakit pada penelitian ini adalah persentase pemakaian tempat tidur $(B O R)$, rata-rata lama dirawatnya seorang pasien (ALOS), frekuensi pemakaian tempat tidur $(B T O)$, rata-rata hari dimana tempat tidur tidak 
ditempati dari telah diisi ke saat terisi berikutnya (TOI), angka kematian 48 jam setelah dirawat untuk tiap 1000 penderita keluar rumah sakit (NDR), angka kematian umum untuk setiap 1000 penderita keluar rumah sakit $(G D R)$.

Perspektif pembelajaran dan pertumbuhan menurut Kaplan dan Norton (1996) membagi tiga kategori utama yaitu kapabilitas pekerja, kapabilitas sistem informasi, motivasi, pemberdayaan dan keselarasan. Dalam organisasi sektor publik perspektif ini memiliki sasaran dan tujuan strategik yang ditetapkan pada perspektif pembelajaran dan pertumbuhan akan berpengaruh terhadap perspektif lain yaitu perspektif proses bisnis internal dan perspektif pelanggan, Beberapa sasaran strategik untuk perspektif ini antara lain : peningkatan keahlian pegawai, peningkatan komitmen pegawai, peningkatan kemampuan membangun jaringan, dan peningkatan motivasi pegawai. Berdasarkan Standar Akreditasi RS 2012 PMKP.3.2 / JCI QPS.3.2 yang mensyaratkan agar RS mengukur harapan dan kepuasan karyawan dan menjadikannya salah satu indikator mutu manajerial, variabel yang digunakan untuk menilai RS pada penelitian ini adalah kepuasan karyawan, retensi karyawan.

Indeks Komposit (IK) merupakan suatu indeks gabungan dari empat perspektif yang diamati, untuk mendapatkan satu persepsi yang utuh tentang kinerja RSUD Wangaya Kota Denpasar. IK dibentuk dengan memberikan bobot pada masing - masing perspektif yang diamati, menurut prioritas penciptaan kinerja RSUD Wangaya Kota Denpasar (Nugrahini, 2016). Penilaian kinerja dengan kerangka $B S C$ memberikan evaluasi kinerja dari empat perspektif secara parsial. Guna mendapatkan hasil penilaian kinerja yang 
komprehensif dan mencerminkan kinerja secara keseluruhan dilakukan dengan IK yang merupakan gabungan dari keempat perspektif kinerja yang diteliti (Nugrahini, 2016)

Pengukuran kinerja merupakan satu proses penilaian kemajuan pekerjaan terhadap pencapaian tujuan dan sasaran yang telah ditentukan, termasuk informasi atas efisiensi penggunaan sumber daya dalam menghasilkan barang dan jasa, kualitas barang dan jasa, perbandingan hasil kegiatan dengan target, dan efektifitas tindakan dalam mencapai tujuan. (Mahmudi, 2010).

Penilaian Kinerja dengan Balanced Scorecard pada Organisasi Sektor Publik adalah satu proses penilaian kemajuan pekerjaan terhadap pencapaian tujuan dan sasaran yang telah ditentukan yang aktifitasnya berhubungan dengan pelayanan publik untuk memenuhi kebutuhan dan hak publik dengan menggunakan empat kartu skor yang berimbang. BSC tidak hanya sekedar alat pengukuran kinerja, namun sebagai sistem manajemen strategik organisasi yang digunakan untuk menterjemahkan visi, misi, tujuan dan strategi organisasi dalam sasaran strategik dan inisiatif strategik yang komprehensif, koheren dan terukur ( Mahmudi, 2010).

\section{METODE PENELITIAN}

Ruang lingkup penelitian ini adalah untuk mengetahui kinerja RSUD Wangaya Kota Denpasar tahun 2014 sampai 2016 dengan menggunakan data primer untuk mengetahui kepuasan pelanggan dan kepuasan karyawan , data 
Ni Nyoman Tri Wahyuni, dan Luh Gede. Sri Artini. Kinerja RSUD Wangaya

sekunder untuk mengetahui rasio keuangan, proses bisnis internal, retensi pelanggan dan akuisisi pelanggan, dan retensi karyawan.

Jenis data yang digunakan dalam penelitian ini adalah data kualitatif berupa kuesioner kepuasan pasien/jasa pengguna RS, kepuasan karyawan dan data kuantitatif dalam penelitian ini adalah untuk perspektif keuangan berupa laporan keuangan, Perspektif proses bisnis internal. perspektif pembelajaran dan pertumbuhan adalah retensi karyawan.

Sumber data yang digunakan dalam penelitian ini adalah data primer diperoleh melalui dihimpun langsung dari responden yang terdiri dari : Pasien RSUD Wangaya Kota Denpasar, Pegawai RSUD Wangaya Kota Denpasar melalui kuesioner dan data sekunder dihimpun dari data RSUD Wangaya Kota Denpasar yang berupa laporan LAKIP, laporan tahunan, laporan keuangan tahun, data rekam medis serta rencana strategis RSUD Wangaya Kota Denpasar tahun 2014 sampai 2016.

Identifikasi variabel yang digunakan dalam penelitian ini yaitu perspektif pelanggan diukur dengan indikator kepuasan pasien/ Pengguna Jasa Rumah Sakit. Perspektif keuangan diukur dengan 2 cara yaitu Rasio keuangan : dengan indikator Rasio Kas (Cash Ratio), Rasio Lancar ( Current Ratio ), Periode Penagihan Piutang ( Collection Period), Perputaran Aset Tetap (Fixed Asset Turnover), Imbalan atas Aktiva Tetap (Return On Asset), Imbalan Ekuitas (Return On Equity) dan Indikator Rasio pendapatan PNBP terhadap biaya operasional. Perspektif Proses Bisnis Internal diukur dengan indikator Bed Occupancy Rate 
(BOR), Average Length Of Stay (ALOS), Bed Turn Over (BTO), Turn Over Interval (TOI), Net Death Rate (NDR), Gross Death Rate (GDR). Perspektif Pembelajaran dan Pertumbuhan diukur dengan indikator kepuasan karyawan, retensi karyawan.

Populasi dalam penelitian ini adalah pasien untuk mengukur kinerja dari perspektif pelanggan dan karyawan untuk mengukur perspektif pembelajaran dan pertumbuhan. Besarnya populasi yang digunakan untuk menentukan sampel pada perspektif pelanggan adalah jumlah pasien rawat inap, rawat jalan dan instalasi gawat darurat, jumlah keseluruhan pasien adalah sebanyak 21.550. Populasi pada perspektif pembelajaran dan pertumbuhan adalah jumlah seluruh karyawan RSUD Wangaya Kota Denpasar, jumlah keseluruhan karyawan adalah sebanyak 970

Sampel yang digunakan dalam penelitian ini adalah dihitung dengan menggunakan rumus Slovin dengan tingkat kesalahan yang diinginkan sebesar $10 \%$ dan pengambilan sampel menggunakan teknik simple/proportional random sampling karena pengambilan sampel dilakukan secara acak/proposional tanpa memperhatikan strata yang ada dalam populasi tersebut. Berdasarkan rumus slovin jumlah sampel pasien yang harus diambil sebesar 100 responden pasien dan sampel karyawan yang harus diambil sebanyak 91 orang karyawan.

Instrumen pengumpulan data dalam penelitian ini menggunakan metode observasi untuk mengumpulkan data pada perspektif keuangan yang digunakan adalah laporan keuangan RS tahun 2014 sampai 2016. Perspektif proses bisnis internal data yang dikumpulkan adalah waktu atas proses yang telah dibangun 
dalam melayani masyarakat tahun 2014 sampai 2016. Perspektif pembelajaran dan pertumbuhan data yang dikumpulkan adalah jumlah karyawan dan karyawan yang keluar /berhenti dari RSUD Wangaya Kota Denpasar tahun 2014 sampai 2016. Penelitian ini juga mengumpulkan data dengan menggunakan kuesioner yang digunakan dalam perspektif pelanggan yaitu untuk mengukur tingkat kepuasan pasien/pengguna jasa RS dan dalam perspektif pembelajaran dan pertumbuhan yaitu mengukur tingkat kepuasan karyawan.

Cara pengumpulan data dalam penelitian ini adalah dengan observasi, perspektif keuangan data yang digunakan adalah laporan keuangan tahun 2014 sampai 2016. Perspektif proses bisnis internal data yang digunakan berdasarkan waktu proses yang telah dibangun dalam melayani masyarakat tahun 2014 sampai 2016, sedangkan untuk perspektif pembelajaran dan pertumbuhan data jumlah retensi karyawan RSUD Wangaya Kota Denpasar tahun 2014 sampai 2016. Kuesioner, metode pengumpulan data dengan kuesioner digunakan pada perspektif pelanggan dan perspektif pembelajaran dan pertumbuhan. Kuesioner dalam penelitian ini menggunakan skala pengukuran empat tingkatan (skala Likert), alternatif jawaban dapat diberi skor dari nilai 1 sampai 4 yaitu Sangat Puas (SP)/ Sangat Setuju (SS) skala likertnya 4, Puas (P)/Setuju (S) skala likertnya 3, Tidak Puas (TP)/Tidak Setuju(TS) dengan skala likertnya 2, dan Sangat Tidak Puas (STP)/Sangat Tidak Setuju (STS) dengan skala likertnya 1.

Metode analisis data dalam penelitian ini ada dua pengujian yang dilakukan yaitu uji Validitas mempunyai koefisien korelasi lebih besar atau minimal 0,3 (Ghozali, 2002). dan Uji Reliabilitas jika nilai Cronbach's Alpha yang diperoleh 
harus lebih besar atau sama dengan 0,60 (Ghozali, 2002. Kedua pengujian ini dilakukan untuk mengetahui validitas dan reliabilitas dari kuesioner yang digunakan.

Teknik analisis data yang digunakan ada dua yaitu analisis rasio dan perhitungan dan analisis kuesioner.

Analisis rasio dan perhitungan :

Perspektif keuangan menggunakan variabel sebagai berikut :

a) Rasio Cas adalah perbandingan kas dan setara kas dengan kewajiban jangka pendek

$$
\text { Rasio Kas }=\frac{\text { Kas dan Setara Kas }}{\text { Kewajiban Jangka Pendek }} \times 100 \%
$$

b) Rasio Lancar adalah untuk mengukur kemampuan RSUD Wangaya dalam membiayai operasional dan memenuhi kewajiban keuangan pada saat ditagih.

$$
\text { Rasio Lancar }=\frac{\text { Aset Lancar }}{\text { Kewajiban Jangka Pendek }} \times 100 \%
$$

c) Periode Penagihan Piutang adalah untuk mengukur berapa lamanya dana ditanamkan dalam piutang atau berapa lama penagihan piutang. Makin kecil rasio ini makin baik karena semakin cepat piutang dilunasi/terkumpul.

$$
\text { Periode Penagihan Piutang }=\frac{\text { Piutang Usaha } x 360}{\text { PendapatanUsaha }} \times 1 \text { Hari. }
$$

d) Perputaran Aset Tetap adalah perbandingan pendapatan operasional dengan aset tetap.

$$
\text { Perputaran Aset Tetap }=\frac{\text { Pendapatan Operasional }}{\text { Aset } T \text { etap }} \times 100 \%
$$

e) Imbalan atas Aktiva Tetap adalah untuk menilai kemampuan RS dalam memperoleh hasil usaha dari layanan yang diberikan. 
Ni Nyoman Tri Wahyuni, dan Luh Gede. Sri Artini. Kinerja RSUD Wangaya

$$
\text { ROA }=\frac{\text { Surplus } / \text { Defisit sebelum Pos Keuntungan } / \text { Kerugian }}{\text { Aset Tetap }} \times 100 \%
$$

f) Imbalan Ekuitas

Rasio ini digunakan untuk menilai kemampuan RS dalam memperoleh hasil usaha dari layanan yang diberikan.

$$
R O E=\frac{\text { Surplus/Defisit sebelum Pos Keuntungan/Kerugian }}{\text { Ekuitas }} \times 100 \%
$$

g) Rasio pendapatan PNBP terhadap biaya operasional

Rasio pendapatan PNBP terhadap biaya operasional adalah perbandingan pendapatan BLU dengan biaya operasional.

Pendapatan PNBP thd biaya operasional $=\frac{\text { Pendapatan } B L U}{\text { Biaya Operasional }} \times 100 \% . .(7)$

Penilaian terhadap variabel perspektif Keuangan pada Tabel 1

Tabel 1

\section{Pengukuran Kinerja Perspektif Keuangan}

\begin{tabular}{lllc}
\hline No & \multicolumn{1}{c}{ Tolok Ukur } & \multicolumn{1}{c}{ Ukuran dengan nilai baik } & Skor \\
\hline 1 & Rasio Kas & $300<\mathrm{RK} \leq 360$ & 10 \\
2 & Rasio Lancar & $600<\mathrm{RL}$ & 13 \\
3 & Periode Penagihan Piutang & PPP $<20$ & 10 \\
4 & Perputaran Aset Tetap & $25<$ PAT & 10 \\
5 & ROA & $9<$ ROA & 5 \\
6 & ROE & $9<$ ROE & 5 \\
\hline
\end{tabular}

Sumber : Peraturan Dirjen Perbendaharaan nomor per 36/PB/2012

1) Perspektif Proses Bisnis Internal menggunakan variabel sebagai berikut :

a) Bed Occupancy Rate (BOR) yaitu persentase pemakaian tempat tidur pada satu satuan waktu tertentu. Variabel ini memberikan gambaran 
tinggi rendahnya tingkat pemanfaatan tempat tidur rumah sakit. Rumus :

$$
B O R=\frac{\text { Jumlah hari Perawatan Rumah Sakit }}{\text { Jumlah Tempat Tidur } X \text { Jumlah hari dalam satu periode }} \times 100 \%
$$

b) Average Length Of Stay (ALOS) yaitu rata-rata lama dirawat seorang pasien. Indikator ini disamping memberikan gambaran tingkat efisiensi, juga dapat memberikan gambaran mutu pelayanan, apabila diterapkan pada diagnosis tertentu dapat dijadikan hal yang perlu pengamatan yang lebih lanjut. Rumus:

$$
\text { ALOS }=\frac{\text { Jumlah Lama Dirawat }}{\text { Jumlah Pasien Keluar (Hidup+Mati) }} \times 100 \%
$$

c) Bed Turn Over (BTO) yaitu frekuensi pemakaian tempat tidur pada satu periode, berapa kali tempat tidur dipakai dalam satu satuan waktu (biasanya dalam periode 1 tahun). Variabel ini memberikan tingkat efisiensi pada pemakaian tempat tidur. Rumus:

$$
\text { BTO }=\frac{\text { Jumlah pasien keluar (hidup+mati) }}{\text { Jumlah tempat tidur }} \times 100 \%
$$

d) Turn Over Interval (TOI) yaitu rata-rata hari dimana tempat tidur tidak ditempati dari telah diisi ke saat terisi berikutnya. Variabel ini juga memberikan gambaran tingkat efisiensi penggunaan tempat tidur. Rumus:

TOI $=\frac{(\text { Jumlah Tempat Tidur } X \text { Periode })-\text { Hari Perawatan }}{\text { Jumlah Pasien Keluar (Hidup+Mati) }} \times 100 \%$

e) Net Death Rate (NDR) yaitu angka kematian 48 jam setelah dirawat untuk tiap-tiap 1000 penderita keluar. Variabel ini memberikan gambaran tingkat efisiensi penggunaan tempat tidur. Rumus:

$N D R=\frac{\text { Jumlah Pasien Mati }>48 \text { Jam Dirawat }}{\text { Jumlah Pasien Keluar (Hidup+Matí) }} \times 1000 \%$ 
Ni Nyoman Tri Wahyuni, dan Luh Gede. Sri Artini. Kinerja RSUD Wangaya

f) Gross Death Rate (GDR) yaitu angka kematian umum untuk setiap 1000 penderita keluar rumah sakit. Rumus:

$G D R=\frac{\text { Jumlah Pasien Mati Seluruhnya }}{\text { Jumlah Pasien Keluar (Hidup+Mati) }} \times 1000 \%$

Penilaian terhadap variabel perspektif Proses Bisnis Internal pada Tabel 2

Tabel 2

Pengukuran Kinerja Perspektif Bisnis Internal

\begin{tabular}{lll}
\hline & Tolok Ukur & Ukuran dengan nilai baik \\
\hline 1 & BOR & $60 \%-85 \%$ \\
2 & ALOS & $6-9$ hari \\
3 & BTO & $40-50$ kali \\
4 & TOI & $1-3$ hari \\
5 & NDR & $<25$ per 1000 \\
6 & GDR & $<45$ per 1000 \\
\hline \multicolumn{2}{l}{ Sumber : Permenkes RI, Nomor $1171 /$ Menkes/Per/VI/2011, Juknis Sirs, tahun 2011}
\end{tabular}

4) Perspektif Pembelajaran dan Pertumbuhan, menggunakan variabel retensi karyawan adalah kemampuan rumah sakit dalam mempertahankan karyawannya, Rumus

$$
R K=\frac{\text { Jumlah Karyawan yang Keluar }}{\text { Total Jumlah Karyawan }} .
$$

Penilaian terhadap variabel perspektif Pembelajaran dan Pertumbuhan pada Tabel 3

Tabel 3

Pengukuran Retensi Karyawan

\begin{tabular}{ccc}
\hline No & Tolok Ukur & Ukuran dengan nilai baik \\
\hline 1 & Retensi Karyawan & $<3 \%$ \\
\hline
\end{tabular}

Sumber : Nizar Alif Utama, 2012

Analisis Data Kuesioner

Analisis data dengan menghitung distribusi dan nilai rata-rata : 
a) Distribusi frekuensi yaitu menghitung jumlah responden yang menyatakan Sangat Puas/Setuju, Puas/Setuju, Tidak Puas/Setuju, dan Sangat Tidak Puas/Setuju.

b) Nilai rata-rata yaitu menghitung nilai rata-rata masing-masing item maupun variabel.

Mutu pelayanan RS dalam akreditasi salah satuya adalah kepuasan pasien yang digunakan untuk memberikan penilain terhadap kinerja RS dan faktor pendukung dari kepuasan pasien adalah bersumber dari kepuasan karyawan yang memberikan pelayanan kesehatan kepada pasien, sehingga standar yang dipergunakan dalam skala pengukuran terhadap kepuasan pelanggan dan karyawan berdasarkan standar pedoman survey kepuasan masyarakat dengan peraturan menteri pendayagunaan aparatur Negara dan reformasi birokrasi Republik Indonesia nomor 16 tahun 2014 tentang Survei Kepuasan Masyarakat yang berpedoman pada Indeks Kepuasan Masyarakat (IKM) KepMenPan No. KEP/25/M.PAN/2/2004 dapat dilihat pada Tabel 4.

Tabel 4

Skala Pengukuran

Tingkat Kepuasan Pelanggan dan Tingkat Kepuasan Karyawan

\begin{tabular}{clllll}
\hline $\begin{array}{c}\text { Nilai } \\
\text { Persepsi }\end{array}$ & Nilai Interval IKM & $\begin{array}{l}\text { Nilai } \\
\text { Konversi IKM }\end{array}$ & $\begin{array}{l}\text { Interval } \\
\text { Pelayanan }\end{array}$ & $\begin{array}{l}\text { Mutu } \\
\text { Pelayanan }\end{array}$ & Unit \\
\hline 1 & $1,00-1,75$ & $25-43,75$ & D & Tidak Baik \\
2 & $1,76-2,50$ & $43,76-62,50$ & C & Kurang Baik \\
3 & $2,51-3,25$ & $62,51-81,25$ & B & Baik \\
4 & $3,26-4,00$ & $81,26-100,00$ & A & Sangat Baik
\end{tabular}

Sumber: Kep/25/M.Pan/2/2004 


\section{Analisis Perhitungan Indeks Keseluruhan Kinerja}

Total bobot kinerja keseluruhan perspektif yaitu 100 persen. IK dibentuk dengan memberikan bobot pada masing - masing perspektif yang diamati. Untuk mengurangi subjektivitas penentuan nilai bobot indikator kinerja nilai ditentukan dengan merata-ratakan pembobotan menurut pendapat masingmasing responden kunci yang diperoleh melalui wawancara kepada direktur RSUD Wangaya Kota Denpasar.

$$
\mathrm{IK}=\frac{30 \%(\mathrm{PP})+20 \%(\mathrm{PK})+30 \%(\mathrm{PI})+20 \%(\mathrm{~PB})}{100 \%}
$$

Nilai IK selanjutnya dipetakan pada kualifikasi penilaian kinerja yang disajikan pada Tabel 5

Tabel 5

Kualifikasi Perhitungan Indeks Komposit

\begin{tabular}{llll}
\hline Nomor & Total Nilai & Kualifikasi & Tingkat keberhasilan \\
\hline 1 & $85-100$ & Sangat baik & Sangat berhasil \\
2 & $70 \leq \mathrm{X}<85$ & Baik & Berhasil \\
3 & $55 \leq \mathrm{X}<70$ & Sedang & Cukup berhasil \\
4 & $\mathrm{X}<55$ & Kurang baik & Tidak berhasil
\end{tabular}

Sumber : Lembaga Administrasi Negara, 1999

Penerapan pola ini akan memberikan kesimpulan kinerja yang dapat berupa kualifikasi atau tingkat keberhasilan. Kualifikasi akan memetakan kinerja sebagai kinerja sangat baik, baik, sedang dan kurang baik. Kesimpulan mengenai tingkat keberhasilan akan memetakan kinerja sebagai kinerja yang sangat berhasil, berhasil, cukup berhasil dan tidak berhasil.

\section{HASIL DAN PEMBAHASAN}

\section{Penilaian Kinerja RSUD Wangaya Perspektif Pelanggan}

a) Hasil Penelitian 
Berdasarkan pedoman survey kepuasan masyarakat dengan peraturan menteri pendayagunaan aparatur Negara dan reformasi birokrasi Republik Indonesia nomor 16 tahun 2014 tentang Survei Kepuasan Masyarakat yang berpedoman pada Indeks Kepuasan Masyarakat (IKM) KepMenPan No. KEP/25/M.PAN/2/2004, dengan menyebarkan kuesioner kepada 100 responden kepada pasien dapat dilihat pada Tabel 6

\section{Tabel 6}

Hasil Perhitungan Perspektif Pelanggan

\begin{tabular}{|c|c|c|c|c|c|c|}
\hline No & Variabel & $\begin{array}{l}\text { Nilai Rata- } \\
\text { rata }\end{array}$ & $\begin{array}{l}\text { Nilai Interval } \\
\text { IKM }\end{array}$ & $\begin{array}{l}\text { Mutu } \\
\text { Pelayanan }\end{array}$ & $\begin{array}{l}\text { Kinerja } \\
\text { Pelayanan }\end{array}$ & Unit \\
\hline 1 & Keandalan & 2,99 & $2,51-3,25$ & B & Baik & \\
\hline 2 & Daya Tanggap & 3,02 & $2,51-3,25$ & B & Baik & \\
\hline 3 & Jaminan & 3,08 & $2,51-3,25$ & B & Baik & \\
\hline 4 & Empati & 3,21 & $2,51-3,25$ & B & Baik & \\
\hline 5 & Bukti Fisik & 3.13 & $2,51-3,25$ & B & Baik & \\
\hline \multicolumn{2}{|c|}{ Jumlah } & 3,08 & $2,51-3,25$ & $\mathrm{~B}$ & Baik & \\
\hline
\end{tabular}

b) Pembahasan

Hasil nilai rata-rata tingkat kepuasan pasien/jasa pengguna RS secara menyeluruh adalah sebesar 3,08 dengan target 4,00 dengan persentase $77,00 \%$. Berdasarkan skala pengukuran IKM, hasil perhitungan tersebut dapat dianalisa bahwa kinerja unit pelayanan tingkat kepuasan pasien/jasa pengguna RS Wangaya memperoleh nilai B (baik).

Berdasarkan perhitungan rata-rata tingkat kepuasan pasien per variabel pada hasil penelitian dapat dilihat bahwa variabel keandalan memperoleh nilai ratarata terkecil yaitu sebesar 2,99. Hal ini menunjukan bahwa kemampuan memberikan pelayanan kesehatan yang dijanjikan secara meyakinkan dan akurat oleh karyawan RS kepada pasien/jasa pengguna RS masih perlu ditingkatkan. 


\section{1) Penilaian Kinerja RSUD Wangaya Perspektif Keuangan}

a) Hasil Penelitian

Penilaian kinerja perspektif keuangan RSUD Wangaya dilakukan terhadap laporan keuangan periode tahun 2014 sampai 2016 melalui perhitungan rasiorasio perspektif keuangan. Hasil perhitungan rasio tersebut disajikan pada Tabel 7

Tabel 7

Rekapitulasi Hasil Perhitungan Rasio Keuangan RSUD Wangaya

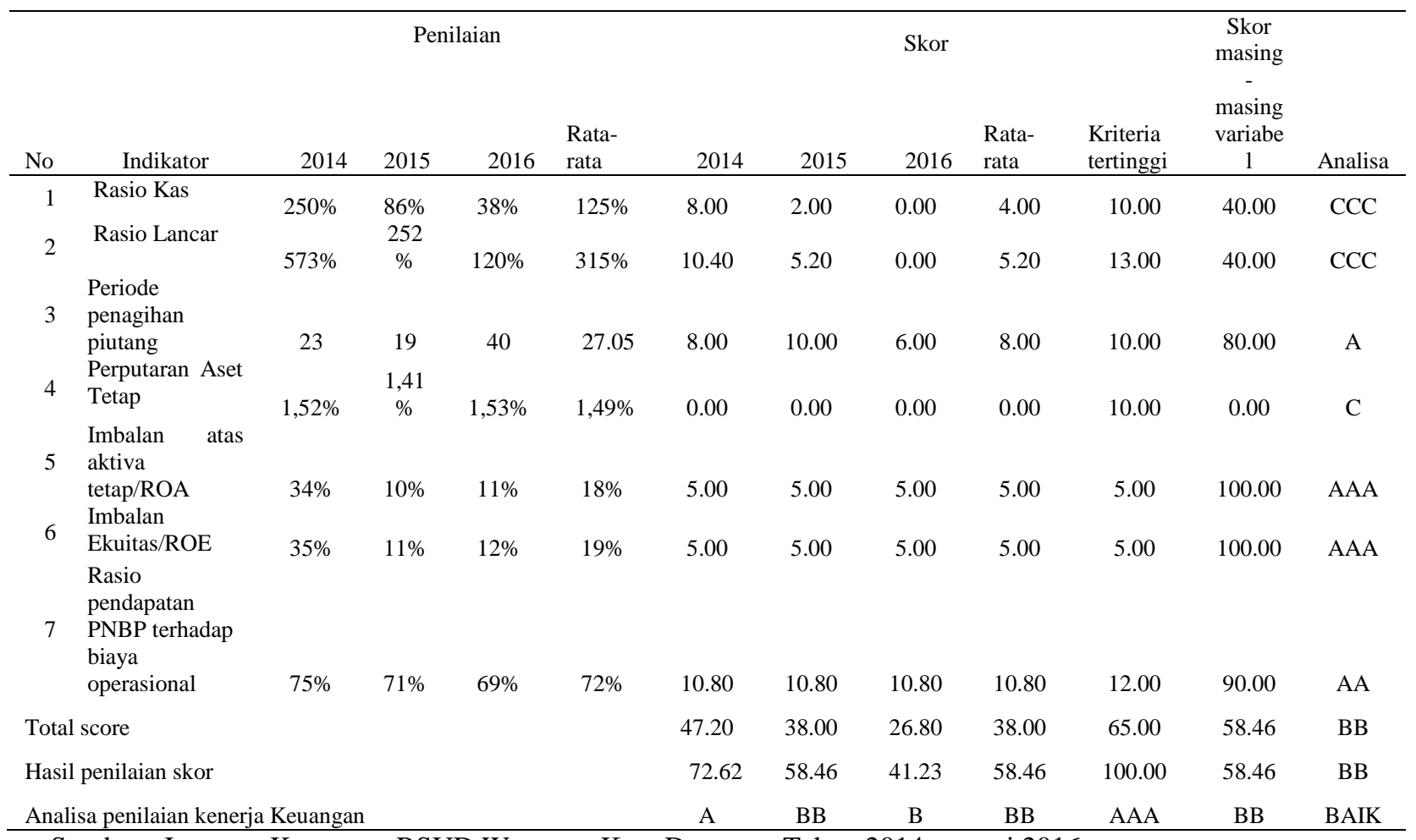

Sumber : Laporan Keuangan RSUD Wangaya Kota Denpasar Tahun 2014 sampai 2016

Hasil perhitungan rata-rata rasio kas pada Tabel 3.2 menunjukkan nilai 125\%, hasil perhitungan rata-rata rasio lancar menunjukkan nilai $315 \%$, hasil perhitungan rata-rata rasio periode penagihan piutang menunjukkan nilai 27,05 hari, hasil perhitungan rata-rata rasio perputaran asset tetap menunjukkan nilai 1,49\%, hasil perhitungan rata-rata ROA menunjukkan nilai $18 \%$, hasil 
perhitungan rata-rata ROE menunjukkan nilai $19 \%$ dan hasil perhitungan rata-rata Rasio pendapatan PNBP terhadap biaya operasional menunjukkan nilai $72 \%$.

b) Pembahasan

Penilaian kinerja keseluruhan rasio keuangan berdasarkan Peraturan Dirjen Perbendaharaan nomor per 36 /PB/2012 dengan rata-rata total skor 38.00 dari target skor 65,00 , diperoleh hasil penilaian sebesar 58,46, dapat digolongkan dalam peringkat Sedang dengan nilai BB (skor diantara $50<\mathrm{TS} \leq 60$ ), sehingga dapat dianalisa rata-rata penilaian kinerja keseluruhan perspektif keuangan RSUD Wangaya Kota Denpasar tahun 2014 sampai 2016 memperoleh kinerja dengan nilai cukup berhasil.

Adapun rata-rata penilaian kinerja yang masih harus ditingkatkan adalah pada rasio kas, rasio lancar, dan rasio perputaran aset tetap, dengan meningkatkan pendapatan dan tetap mengefisienkan biaya RS, kewajiban jangka pendek yang tinggi tidak seiring dengan kas tunai karena pendapatan yang menurun, sehingga harus meningkatkan pendapatan. Rasio perputaran asset tetap rendah karena adanya penurunan pendapatan operasional RS tetapi jumlah aset tetap RS justru meningkat, sehingga pendapatan RS harus ditingkatkan.

\section{c) Penilaian Kinerja RSUD Wangaya Perspektif Proses Bisnis Internal}

a) Hasil Penelitian

Hasil perhitungan dari proses bisnis internal dari tahun 2014 sampai 2016 dapat dilihat pada Tabel 8 
Tabel 8

\section{Rekapitulasi Hasil Perhitungan Kinerja Perspektif Proses Bisnis} Internal RSUD Wangaya

\begin{tabular}{|c|c|c|c|c|c|c|c|c|c|c|}
\hline \multirow{3}{*}{ No. } & \multirow{2}{*}{ Uraian } & \multirow{3}{*}{ Nilai Ideal } & \multicolumn{3}{|c|}{ Realisasi } & \multirow{3}{*}{ Rata-rata } & \multirow{3}{*}{$\begin{array}{l}\text { Krite } \\
\text { ria } \\
\text { penil } \\
\text { aian } \\
\end{array}$} & \multirow{2}{*}{$\begin{array}{c}\text { Kriteria } \\
\text { terting } \\
\text { gi }\end{array}$} & \multirow{2}{*}{$\begin{array}{c}\text { Kriteria } \\
\text { masing- } \\
\text { masing } \\
\text { variabel }\end{array}$} & \multirow{2}{*}{ Analisis } \\
\hline & & & 2014 & 2015 & 2016 & & & & & \\
\hline & BOR (Bed Occupancy & & & 79.4 & & & & & & \\
\hline 1 & Ratio) & $60-85 \%$ & 80.70 & 4 & 90.05 & $83.39 \%$ & 3 & 3 & $100.00 \%$ & Baik \\
\hline 2 & ALOS (Length Of Stay) & 6-9 hari & 4.19 & $\begin{array}{l}4.39 \\
64.2\end{array}$ & 4.27 & 4.28 & 2 & 3 & $66.67 \%$ & Cukup \\
\hline 3 & BTO (Bed Turn Over) & 40-50 kali & 67.87 & 1 & 74.76 & 68.94 & 2 & 3 & $66.67 \%$ & Cukup \\
\hline 4 & TOI (Turn Over Internal) & 1-3 hari & 1.04 & $\begin{array}{l}1.17 \\
26.4\end{array}$ & 0.49 & 0.90 & 2 & 3 & $66.67 \%$ & Cukup \\
\hline 5 & NDR (Net Death Rate) & $<25$ permil & 26.67 & $\begin{array}{c}8 \\
43.5\end{array}$ & 22.94 & $25.36 \%$ o & 2 & 3 & $66.67 \%$ & Cukup \\
\hline 6 & GDR (Gross Date Rate) & $\leq 45$ permil & 42.29 & 3 & 37.59 & 41.14\%。 & 3 & 3 & $100.00 \%$ & Baik \\
\hline Total & Kriteria & & & & & & 14 & 18 & $77.78 \%$ & Baik \\
\hline
\end{tabular}

Sumber : Laporan Rekam Medis RSUD Wangaya Kota Denpasar Tahun 2014 sampai 2016

Hasil perhitungan rata-rata $B O R$ pada Tabel 3.3 menunjukkan nilai 83,39\%, hasil perhitungan rata-rata $A L O S$ menunjukkan nilai 4,28 hari, hasil perhitungan rata-rata $B O R$ menunjukkan nilai 68,94 hari, hasil perhitungan rata-rata $T O I$ menunjukkan nilai 0,90 hari, hasil perhitungan rata-rata $N D R$ menunjukkan nilai 25,36\%o, hasil perhitungan rata-rata GDR menunjukkan nilai 41,14\%o

b) Pembahasan

Penilaian kinerja proses bisnis internal RS Wangaya secara keseluruhan memperoleh hasil perhitungan 14,00 dari target 18,00 diperoleh hasil penilaian sebesar 77,78\% dapat digolongkan dalam kualifikasi penilaian diantara $70 \leq \mathrm{X}<$ 85, sehingga rata-rata penilaian kinerja keseluruhan perspektif proses bisnis internal RSUD Wangaya Kota Denpasar tahun 2014 sampai 2016 diperoleh kualifikasi dalam kategori baik / berhasil.

d) Penilaian Kinerja RSUD Wangaya Perspektif Pembelajaran dan

\section{Pertumbuhan}


a) Hasil Penelitian

Penilaian kinerja perspektif pembelajaran dan pertumbuhan RSUD Wangaya diukur melalui tingkat retensi karyawan dan tingkat kepuasan karyawan. Hasil perhitungan tingkat retensi karyawan dapat dilihat pada Tabel 9

Tabel 9. Rekapitulasi Hasil Perhitungan Tingkat Retensi Karyawan RSUD Wangaya

\begin{tabular}{cccc}
\hline Tahun & $\begin{array}{c}\text { Jumlah } \\
\text { Karyawan } \\
\text { (Orang) }\end{array}$ & $\begin{array}{c}\text { Jumlah Karyawan } \\
\text { Keluar (Orang) }\end{array}$ & $\begin{array}{c}\text { Tingkat Retensi } \\
\text { Karyawan (\%) }\end{array}$ \\
\hline 2014 & 838 & 29 & 3 \\
2015 & 887 & 15 & 2 \\
2016 & 973 & 19 & 2 \\
Rata-rata & 899 & 21 & 2 \\
\hline
\end{tabular}

Sumber : Laporan Kepegawaian RSUD Wangaya Kota Denpasar Tahun 2014 sampai 2016

Retensi karyawan RSUD Wangaya dari tahun ke tahun mengalami perubahan, dimana rata-rata perubahan jumlah karyawan yang keluar dari tahun 2014 sampai 2016 sebanyak 21 orang, dari rata-rata jumlah karyawan sebanyak 899 orang, dengan rata-rata tingkat persentase retensi karyawan $2 \%$

b) Pembahasan

Hasil perhitungan rata-rata retensi karyawan sebesar $2 \%$, sedangkan standar yang dipergunakan pada penelitian ini adalah 3\%, hal ini menunjukan bahwa RS Wangaya sudah mampu mempertahankan karyawannya dengan baik karena tingkat retensi karyawan RS kurang dari standar yang ada, Karyawan yang keluar/berhenti dari RS Wangaya disebabkan karena karyawan tersebut telah memasuki usia pensiun, mutasi ke instansi lain/ luar daerah, meninggal karena sakit, mengundurkan diri ( masih kontrak melanjutkan pendidikan, pindah tempat kerja). 
Penilaian kinerja perspektif pembelajaran dan pertumbuhan RSUD Wangaya yang lainnya dapat diukur melalui tingkat kepuasan karyawan.

a) Hasil Penelitian

Tingkat kepuasan karyawan berdasarkan standar akreditasi RS 2012 PMKP.3.2 / JCI QPS.3.2 yang menggunakan standar pedoman survey kepuasan masyarakat dengan peraturan menteri pendayagunaan aparatur Negara dan reformasi birokrasi Republik Indonesia nomor 16 tahun 2014 tentang Survei Kepuasan Masyarakat yang berpedoman pada Indeks Kepuasan Masyarakat (IKM) KepMenPan No. KEP/25/M.PAN/2/2004, dengan menyebarkan kuesioner kepada 91 responden kepada karyawan RSUD Wangaya dapat dilihat pada Tabel 10

\section{Tabel 10}

Penilaian Kinerja Perspektif Karyawan

\begin{tabular}{clcccc}
\hline No & \multicolumn{1}{c}{ Variabel } & $\begin{array}{c}\text { Nilai Rata- } \\
\text { rata }\end{array}$ & $\begin{array}{l}\text { Nilai } \\
\text { Interval }\end{array}$ & $\begin{array}{l}\text { Mutu } \\
\text { Pelayanan }\end{array}$ & $\begin{array}{l}\text { Kinerja Unit } \\
\text { Pelayanan }\end{array}$ \\
\hline 1 & Kerja secara mental & 3,12 & $2,51-3,25$ & B & Baik \\
2 & Kompensasi & 2,90 & $2,51-3,25$ & B & Baik \\
3 & Kondisi Kerja & 3,06 & $2,51-3,25$ & B & Baik \\
4 & Rekan Kerja & 3,06 & $2,51-3,25$ & B & Baik \\
5 & Kesesuaian Kepribdian & 3.08 & $2,51-3,25$ & B & Baik \\
Jumlah & 3,04 & $2,51-3,25$ & B & Baik \\
Sumber : Kuesioner Kepuasan Karyawan RSUD Wangaya Kota Denpasar Tahun 2014 sampai \\
2016
\end{tabular}

a) Pembahasan

Hasil nilai rata-rata tingkat kepuasan karyawan RS secara menyeluruh adalah sebesar 3,04 dengan target 4,00, dilihat dari persentase 76,00\%. Berdasarkan skala pengukuran IKM, hasil perhitungan tersebut dapat dianalisa bahwa kinerja 
unit pelayanan tingkat kepuasan karyawan RS Wangaya memperoleh nilai B (baik).

Berdasarkan perhitungan rata-rata tingkat kepuasan karyawan per variabel pada hasil penelitian dapat dilihat bahwa variabel kompensasi memperoleh nilai rata-rata terkecil yaitu sebesar 2,90. Hal ini menunjukan bahwa imbalan kerja yang diberikan, jenjang karier, penghargaan atas prestasi kerja serta jaminan kerja masih harus ditingkatkan supaya kepuasan karyawan meningkat.

\section{e) Penilaian Kinerja RSUD Wangaya Secara Keseluruhan}

Untuk mengetahui kinerja RSUD Wangaya dengan menggunakan metode BSC secara keseluruhan maka dilakukan perhitungan dengan indeks komposit. Indeks komposit ini dihitung dengan cara memberikan bobot pada masing-masing perspektif BSC sehingga nantinya akan diperoleh hasil akhir yang mencerminkan kinerja RSUD Wangaya secara keseluruhan. Bobot ini diperoleh berdasarkan hasil wawancara dengan direktur RSUD Wangaya Kota Denpasar, adapun hasil dari wawancara yang dilakukan adalah sebagai berikut :

$\mathrm{IK}=\underline{30 \%(77)+20 \%(58)+30 \%(78)+20 \%(76)}$

$100 \%$

Perhitungan Indeks Komposit dilakukan dengan cara bobot dikali dengan masing-masing variabel pada keempat perspektif.

a) Hasil Penelitian

Hasil perhitungan indeks komposit dapat dilihat pada Tabel 6 dibawah ini. 
Tabel 11

Hasil Perhitungan Indeks Komposit dari Rata-rata Kinerja RSUD Wangaya Berdasarkan BSC Tahun 2014 sampai 2016

\begin{tabular}{|c|c|c|c|c|c|}
\hline No & Perspektif & Bobot & $\begin{array}{l}\text { Rata-Rata } \\
\text { Nilai } \\
\text { Kinerja }\end{array}$ & $\begin{array}{l}\text { Persentase } \\
\text { dari rata- } \\
\text { rata kinerja }\end{array}$ & $\begin{array}{l}\text { Indeks } \\
\text { Komposi } \\
t\end{array}$ \\
\hline 1 & $\begin{array}{l}\text { Pelanggan } \\
\text { (Kepuasan pasien/jasa pengguna RS) }\end{array}$ & $30 \%$ & 3,08 & $77 \%$ & $23 \%$ \\
\hline 2 & $\begin{array}{l}\text { Keuangan } \\
\text { (Perben no. 36/PB/2012) }\end{array}$ & $20 \%$ & 38 & $58 \%$ & $12 \%$ \\
\hline 3 & $\begin{array}{l}\text { Proses Bisnis Internal } \\
\text { (Permenkes No. } \\
\text { 1171/Menkes/Per/VI/2011) }\end{array}$ & $30 \%$ & 14 & $78 \%$ & $23 \%$ \\
\hline 4 & $\begin{array}{l}\text { Pembelajaran dan Pertumbuhan } \\
\text { (Kepuasan Karyawan) }\end{array}$ & $20 \%$ & 3,04 & $76 \%$ & $15 \%$ \\
\hline \multicolumn{2}{|c|}{ Jumlah } & $100 \%$ & & $73 \%$ & $73 \%$ \\
\hline
\end{tabular}

Sumber : Hasil Gabungan Perspektif

Hasil perhitungan rata- rata indeks komposit dari tahun 2014 sampai 2016 menunjukkan bahwa perspektif pelanggan memperoleh nilai $23 \%$, perspektif keuangan memperoleh nilai $12 \%$, perspektif proses bisnis internal memperoleh nilai $23 \%$, perspektif pembelajaran dan pertumbuhan memperoleh nilai $15 \%$

b) Pembahasan

Berdasarkan Tabel 5.20 diperoleh hasil persentase dari rata-rata kinerja dari masing-masing perspektif dan indeks komposit dari kinerja RSUD Wangaya secara keseluruhan, namun sebelum memberikan penilaian terhadap kinerja RS, maka harus mengetahui kualifikasi penilaian kinerja yang berdasarkan pada sumber lembaga administrasi Negara, 1999. Berdasarkan Pengklasifikasian hasil yang diperoleh dalam perhitungan indeks komposit ini akan memberikan kesimpulan kinerja yang berupa kualifikasi atau tingkat keberhasilan. 
Tabel 12

Hasil Penilaian Indeks Komposit

\begin{tabular}{|c|c|c|c|c|c|c|}
\hline No & Perspektif & $\begin{array}{c}\text { Indeks } \\
\text { Komposi } \\
t\end{array}$ & $\begin{array}{c}\text { Pencapai } \\
\text { an } \%\end{array}$ & Standar & $\begin{array}{c}\text { Kualifikas } \\
\text { i }\end{array}$ & $\begin{array}{c}\text { Tingkat } \\
\text { keberhasilan }\end{array}$ \\
\hline 1 & Pelanggan & $23 \%$ & $77 \%$ & $70 \leq X<85$ & Baik & Berhasil \\
\hline 2 & Keuangan & $12 \%$ & $58 \%$ & $55 \leq X<70$ & Sedang & $\begin{array}{l}\text { Cukup } \\
\text { Berhasil }\end{array}$ \\
\hline 3 & $\begin{array}{l}\text { Proses Bisnis } \\
\text { Internal }\end{array}$ & $23 \%$ & $78 \%$ & $70 \leq X<85$ & Baik & Berhasil \\
\hline 4 & $\begin{array}{l}\text { Pembelajaran } \\
\text { dan } \\
\text { pertumbuhan }\end{array}$ & $15 \%$ & $76 \%$ & $70 \leq X<85$ & Baik & Berhasil \\
\hline \multicolumn{2}{|c|}{ Jumlah } & $73 \%$ & $73 \%$ & $70 \leq X<85$ & Baik & Berhasil \\
\hline
\end{tabular}

Hasil nilai indeks komposit memperoleh nilai 73\%, hal ini menunjukan bahwa secara keseluruhan kinerja RSUD Wangaya Kota Denpasar dengan menggunakan metode BSC dapat dikatakan mempunyai kualifikasi dengan nilai "Baik" dengan tingkat keberhasilan tergolong "Berhasil" hal ini dikarenakan karyawan sudah mendapatkan kesejahteraan karyawan cukup terjamin dan keahlian yang diberikan RS dalam bentuk pelatihan berjalan baik sehingga mampu dalam memberikan pelayanan kesehatan yang baik kepada pasien (masyarakat) dan karyawan mempunyai keahlian dalam melaksanakan proses aktifitas internal RS dengan baik, sehingga masyarakat merasa puas dengan pelayanan yang diberikan oleh pihak RS.

Berdasarkan hasil indeks komposit, perspektif yang memperoleh hasil indeks komposit paling rendah adalah perspektif keuangan yaitu sebesar $12 \%$ dari target $20 \%$ sehingga persentase pencapaiannya sebesar $58 \%$, hal ini menunjukan bahwa perspektif keuangan belum maksimal dalam pengelolaan keuangannya, maka harus meningkatkan kinerjanya supaya dapat mengelola keuangan secara mandiri karena merupakan tuntutan dalam organisasi sektor publik. 


\section{SIMPULAN DAN SARAN}

Berdasarkan atas hasil penelitian dan pembahasan pada bab sebelumnya, maka dapat disimpulkan sebagai berikut : Penilaian kinerja pada perspektif pelanggan dengan nilai rata-rata kepuasan pasien/jasa pengguna RS sebesar 3,08 (skala nilai tertinggi 4) dan dinilai dari persentase rata-rata kinerja diperoleh nilai $77 \%$ yang dapat dikualifikasikan/tingkat keberhasilan dalam kategori baik / berhasil, artinya RS Wangaya sudah memberikan pelayanan kesehatan dengan baik. Untuk meningkatkan nilai dari kinerja pelanggan maka variabel keandalan perlu diperhatikan. Penilaian kinerja pada perspektif keuangan dengan nilai ratarata sebesar 58\% yang dapat dikualifikasikan dalam kategori sedang / cukup berhasil, artinya kinerja keuangan RS sebagian besar sudah mampu berkinerja dengan baik seperti penilaian periode penagihan piutang sudah mampu menagih piutang $\mathrm{RS}$ dalam periode tertentu, penilaian rasio $R O A$ sudah mampu memperoleh keuntungan dari segi penggunaan aset dengan baik, penilaian rasio $R O E$ sudah mampu memperoleh keuntungan dari segi penggunaan modal pemilik atau modal yang ditanamkan oleh pemilik RS Wangaya. Penilaian rasio pendapatan PNBP terhadap biaya operasional sudah mampu mengelola keuangan dari segi pendapatan dan meminimalkan biaya. Berdasarkan Tabel 5.7 penilaian kinerja yang masih kurang sehingga perlu diperhatikan dan ditingkatkan adalah pada rasio kas, rasio lancar, dan rasio perputaran aset tetap. Penilaian kinerja pada perspektif proses bisnis internal memperoleh nilai rata-rata sebesar 78,00\%, dapat digolongkan dalam kualifikasi kategori baik / berhasil, artinya RS Wangaya sudah mampu membangun keunggulan $\mathrm{RS}$ melalui proses internal RS secara 
berkelanjutan, seperti penilaian $B O R$ menunjukkan kondisi tingkat hunian rumah sakit sudah baik, penilaian GDR yang menunjukan kondisi angka kematian pasien untuk tiap 1000 pasien yang keluar dari RS sudah baik. Sebagian kinerja yang menunjukan kinerja cukup yang perlu diperhatikan dan ditingkatkan adalah kinerja ALOS, BTO, TOI NDR. Penilaian kinerja Perspektif Pembelajaran dan Pertumbuhan menunjukkan tingkat retensi karyawan dan kuesioner kepuasan karyawan, tingkat retensi karyawan di nilai baik yaitu sebesar 2\% dari standar 3\%, hal ini menunjukan bahwa RS Wangaya sudah mampu mempertahankan karyawannya untuk bekerja di RS Wangaya. Tingkat kepuasan karyawan memperoleh nilai rata-rata sebesar 3.04 (skala nilai tertinggi 4) dan dinilai dari persentase memperoleh nilai $76 \%$ yang dapat dikualifikasikan/tingkat keberhasilan dalam kategori baik / berhasil, artinya karyawan RS dapat dikategorikan puas yaitu dapat dilihat dari RS mampu mempertahankan karyawannya untuk bekerja di RS Wangaya dan menunjukan kinerja pelayanan, proses bisnis internal dan keuangan dengan baik. Untuk meningkatkan nilai dari perspektif ini maka variabel kompensasi perlu diperhatikan. Penilaian kinerja RSUD Wangaya Kota Denpasar secara keseluruhan yang berbasis BSC rata-rata dari tahun 2014 sampai 2016 dengan menggunakan indek komposit memperoleh nilai sebesar 73\%, artinya kinerja RSUD Wangaya Kota Denpasar dengan menggunakan metode BSC memperoleh kualifikasi dengan nilai "Baik" dan tingkat keberhasilan tergolong "Berhasil", artinya karyawan mampu dalam memberikan pelayanan yang baik kepada masyarakat sehingga masyarakat merasa 
Ni Nyoman Tri Wahyuni, dan Luh Gede. Sri Artini. Kinerja RSUD Wangaya

puas dengan pelayanan yang diberikan dengan mengutamakan proses aktifitas pelayanan, sesuai dengan visi dan misi RS.

Berdasarkan hasil temuan dan kesimpulan maka disarankan beberapa hal penting sebagai berikut : Perspektif pelanggan pada tingkat kepuasan pasien/jasa pengguna RS masih perlu ditingkatkan pada variabel keandalan dengan cara :

a) Menjalankan jadwal buka pelayanan tepat waktu sehingga pasien yang mengantri saat pendaftaran periksa pasien tidak terlalu lama; b) Membuat prosedur pelayanan mudah dan cepat sehingga pasien mudah melakukan akses pemeriksaan; c) Meningkatkan penanganan keluhan pasien dengan cepat; d) Mempermudah administrasi pasien; e) Meningkatkan tanggung jawab petugas dalam melaksanakan pelayanan; f) Meningkatkan pelayanan kesehatan pasien secara adil tanpa melihat status pasien. Perspektif keuangan yang perlu diperhatikan dan ditingkatkan adalah : Rasio kas dan rasio lancar, dengan cara mengevaluasi rencana pendapatan RS kedepannya dan membuat strategi untuk mewujudkan realisasi pendapatan serta meminimalkan biaya operasional RS seperti biaya ATK, alat kebersihan, alat cetak dan untuk utang salah satunya dengan cara mengkaji kembali pembelian obat yang pergerakannya lambat dan obat yang pergerakannya cepat (fast moving) cukup untuk persediaan satu bulan. Rasio perputaran aset tetap dengan cara meningkatkan pendapatan operasional RS yaitu memberikan pelayanan kepada pasien dengan baik dan ramah, meningkatkan promosi sehingga pasien umum lebih memilih RS Wangaya sebagai tempat berobat yang sesuai dengan harapan dengan 
memberikan pelayanan yang baik, biaya yang terjangkau, fasilitas yang lengkap sehingga menarik minat masyarakat untuk memeriksakan kesehatannya ke RS Wangaya. Perspektif proses bisnis internal yang masih perlu diperhatikan adalah : Kinerja ALOS, BTO, TOI disarankan untuk menambah tempat tidur pasien yang yang sebelumnya 200 tempat tidur, sekarang dimiliki RS sebanyak 220 tempat tidur. Penilaian kinerja $N D R$ disarankan memberikan edukasi tentang pola hidup sehat kepada masyarakat, dampak dari tidak melakukan pemeriksaan secara rutin mengenai kesehatan kepada masyarakat, meningkatkan pengetahuan tentang pengenalan dan penanganan penyakit kronis ke tenaga medis, paramedis yang bekerja di puskesmas dan RS sekitarnya, meningkatkan sarana dan prasarana alat kesehatan RS Wangaya, meningkatkan kemampuan SDM dengan memberikan pelatihan, workshop tentang penanganan pasien kronis dan regeneratif. Perspektif pembelajaran dan pertumbuhan pada tingkat kepuasan karyawan yang perlu diperhatikan dan ditingkatkan pada variabel kompensasi adalah : Kompensasi, besarnya imbalan kerja yang diberikan kepada karyawan akan menumbuhkan semangat kerja sehingga berpengaruh terhadap tugas dan tanggung jawab dalan pekerjaan; Jenjang karier, dengan memperhatikan jenjang karier karyawan akan ada motivasi kerja untuk lebih baik; Penghargaan atas prestasi kerja, dengan memberikan penghargaan terhadap karyawan yang berprestasi, maka akan ada peningkatan kinerja karyawan; Jaminan kerja, dengan memberikan jaminan kerja kepada karyawan maka karyawan 
merasa dilindungi yang dapat menumbuhkan dan meningkatkan kepuasan karyawan.

\section{Impikasi Penelitian}

Hasil penelitian ini menunjukkan penilaian kinerja RS berbasis BSC lebih mampu menggambarkan kondisi RS secara keseluruhan tidak hanya berdasarkan perspektif keuangan tetapi juga berdasarkan perspektif non keuangan. dengan melakukan penilaian terhadap perspektif non keuangan akan terlihat faktor pendorong yang sebenarnya dari perspektif keuangan, sehingga ketika perusahaan melakukan perubahan terhadap perspektif non keuangan, mereka bisa melihat dampaknya terhadap perspektif keuangan. Jadi, ketika RS ingin meningkatkan kinerja perspektif keuangan, maka juga harus memperhatikan perspektif non keuangan sehingga keputusan yang dibuat akan lebih menyeluruh dan berjangka panjang.

Secara keseluruhan rata-rata penilaian kinerja RSUD Wangaya dari tahun 2014 sampai 2016 yang berbasis BSC dapat dikatagorikan baik / berhasil, sehingga penilaian yang diperoleh dari penelitian ini mampu menjadi dasar pertimbangan bagi manajemen agar bisa mengambil keputusan yang tepat bagi RSUD Wangaya Kota Denpasar untuk kedepannya.

\section{REFERENSI}

Abdel at el. 2014.The Impact of Strategic Management on the Jordanian Pharmaceutical Manufacturing Organizations Business Performance, International Journal Review dari Manajemen dan Bisnis Research, Vol. 3 Issue.2, Juni 2014. 
Ayesha Farooq at el. 2011. Balanced Scorecard Perspective On Change And Performance : a study of selected Indian Companies, International Journal Strategic Management Conference, Procedia Social and Behavioral Sciences 242011.

Barbara Bigliardi. 2011. Balanced Scorecard For The Public Administration : Issues From a Case Study, International Journal Of Business, Management and Social Scinces. Vol. 2, No.5, 2011.

Deryl Northcott. 2011. Using the balanced scorecard to manage performance in public sector organizations Issues and challenges, International Journal of Public Sector Management Vol. 25 No. 3, 2012.

Farshad Behrouzi. 2014. Applications Of The Balanced Scorecard For Strategic Management And Performance Measurement In The Health Sector, Journal compilation, 4 March 2014.

Fatmanelly. 2011. Analisis Kinerja RSUD dr. Adnaan WD Tahun 2010 dengan Metoda Balanced Scorecard, Jurnal Nasional Universitas Padang, Sumatra Barat.

Hsueh-Fen Chen at el. 2012. Application of the balanced scorecard to an academic medical center in Taiwan: The effect of warning systems on improvement of hospital performance, Journal of the Chinese Medical Association 75 (2012) 530-535.

Ida Ayu Putu Nugrahini. 2016. Tesis Penilaian Kinerja Badan Badan Penanaman Modal dan Perijinan Daerah (BPMPD) Kabupaten Tabanan Berdasarkan Balanced Scorecard, Fakultas Ekonomi Universitas Udayana Denpasar.

Keputusan Menteri Pendayagunaan Aparatur Negara Nomor Kep/25/M.Pan/2/2004, Pedoman Umum Penyusunan Indeks Kepuasan Masyarakat Unit Pelayanan Instansi Pemerintah, Jakarta

Mahmudi. 2010. Manajemen Kinerja Sektor Publik, Yogyakarta, Pebruari 2010.

Mardiasmo. 2002. Akuntansi Sektor Publik. Penerbit Andi Yogyakarta, Yogyakarta.

Nizar Alif Utama. 2012. Analisis Pengukuran Kinerja Rumah Sakit dengan Pendekatan Balanced Scorecard (Studi Kasus Pada RSUD. Prof Soekandar Mojosari), Jurnal Nasional, Universitas Brawijaya, Jl. MT. Haryono 165, Malang.

Peraturan Menteri Pendayagunaan Aparatur Negara dan Reformasi Birokrasi 
Ni Nyoman Tri Wahyuni, dan Luh Gede. Sri Artini. Kinerja RSUD Wangaya

Republik Indonesia nomor 16 tahun 2014, Survei Kepuasan Masyarakat, Kementerian Pendayagunaan Aparatur Negara Republik Indonesia, Jakarta.

Peraturan Menteri Kesehatan Nomor 1171/Menkes/Per/VI/2011. Sistem Informasi rumah sakit, Juknis Sirs, Menteri Kesehatan Republik Indonesia, Jakarta.

Peraturan Direktur Jenderal Perbendaharaan nomor per 36 /PB/2012. Pedoman penilaian kinerja keuangan satuan kerja badan layanan umum direktur jenderal perbendaharaan, Kementerian keuangan Republik Indonesia Direktorat Jenderal Perbendaharaan Jakarta.

Robert S.Kaplan dan David P.Norton, 1996. Menerapkan Strategi Menjadi Aksi Balanced Scorecard, Penerbit. Erlangga, Jakarta.

Seth A., Oyugi L.A. 2013. Influence of Balanced Scorecard on Organization Performance in Institutions of Higher Learning in Kenya. A Case Study of University of Nairobi. International Journal of Education and Research, Vol. 1 No. 8 August 2013.

Suparto Adikoesoemo.Dr, 2002. Manajemen Rumah Sakit, Jakarta: Pustaka Sinar Harapan. 